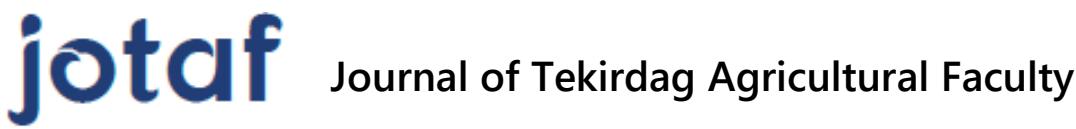

Mayıs/May 2020, 17(2)

Başvuru/Received: 29/01/19

Kabul/Accepted: 22/08/19

DOI:10.33462/jotaf./jotaf.518975

Tekirdağ Ziraat Fakültesi Dergisi

http://dergipark.gov.tr/jotaf

http://jotaf.nku.edu.tr/

ARAŞTIRMA MAKALESİ

RESEARCH ARTICLE

\section{Ramifications of Households Non-farm Income on Agricultural Productivity: Evidence from Rural Area of Pakistan}

\author{
Salamun RASHIDİN ${ }^{1}$, Sara JAVED ${ }^{2}$, Bin Lİ ${ }^{3}$
}

\begin{abstract}
In Pakistan, agriculture sector currently contributes up to 28 percent to in GDP. Due to the development of modern science and technology, rural household source of income is altering. Lots of research suggested that non-farm income is the main source of income for rural area. This study investigates the effects of non-farm income on agriculture productivity in Pakistan. The current research accumulated data from Pakistan Social and Living Standards Measurement Survey (PSLM) 2014-15. Pakistan Federal Bauru of Statistics has developed its own sampling frame for rural and urban areas. Researcher used the Heckman's two-step procedure to tackle the problem of endogeneity and selection bias. The first phase of probit regression coefficient indicates that the availability of banks, motorable roads, forest, telecommunication substructure, montane grasslands and shrublands zone are substantial to clarify the non-farm income. On the other hand, the second stage of OLS regression exhibited a significant negative association between non-farm income and per-capita farm income.
\end{abstract}

Keywords: Agricultural Productivity; Non-farm income; Endogeneity

\footnotetext{
1*Sorumlu Yazar/Corresponding Author: Salumun Rashidin, China Institute for WTO studies, University of International Business and Economics, Beijing, China. E-mail: salamun.du@ outlook.com (iD) OrcID: 0000-0003-1273-8494

${ }^{2}$ Sara Javed, Scholar Department of Marketing, University of International Business and Economics, Beijing, China.. E-mail: sarawarriach@outlook.com OrcID: 0000-0002-7234-7690

${ }^{3}$ Bin Liu, China Institute for WTO studies, University of International Business and Economics, Beijing, China. E-mail: liubin@ uibe.edu.cn. 10 OrcID:0000-00028271-4941

Atıf/Citation: Rashidin, S., Javed, S, Liu, B. 2020. Ramifications of households non-farm income on agricultural productivity: evidence from rural area of Pakistan. Tekirdağ Ziraat Fakültesi Dergisi, 17(2), 108-123.

*Bu çalışma Yüksek Lisans tezinden özetlenmiştir.

CBu çalışma Tekirdağ Namık Kemal Üniversitesi tarafindan Creative Commons Lisansı (https://creativecommons.org/licenses/by-nc/4.0/) kapsamında yayınlanmıştır. Tekirdağ 2019
} 
Agriculture sector of Pakistan accounts for 28 percent of the country's GDP (GoP, 2015). Rural household's source of revenue is changing day by day. Lots of research suggested that non-farm income is the main source of income for rural area (Ellis and Mdoe 2003). With the development of modern science household income expansion is becoming prevalent in the rural civilizations and people from rural areas are specialized on expanding household income. For this expansion, rural households earn extra income and develop their wellbeing (Dimova and Sen, 2010). In the present situation, non-farm income holds the attention of researchers to deepens their knowledge on this area and, in addition, on how and why households changed their income situation. This research also contributes to the enumerating the segment of non-farm income from the total income portfolio and also identifies the energetic factor to diversify exterior agriculture. This research also inspects evenhandedness and food security insinuations. Notional enlightenment assures that there is pull or push factor that changes the households (Ellis, 2000; Barrett et al., 2001). Contribution in non-farm income accomplishments is also the consequence of push and pull factors, because of the definite contribution of households in non-farm accomplishments relies on the incentive and capability to contribute and the existence of entry barriers ((Reardon 1997).

These two conflicting forces regulate the influences of changing income sources. Most of the time, push factor is innate and frantic reason for change. It includes income risk management, long-term restraints, flattening household ingesting handling instruments (Ellis 2000; Barrett et al. 2001;Reardon et al. 2001). Lots of research has been done on pull factor, it attracts the households to the non-farm sector where they get more in return than farming. People of low income/ the poor are mostly interested in low risk rural non farming service even they know they might have low returns (Reardon et al. 2001). Unemployment and poverty is the main challenge for the policy makers in the existing developing nation. For the developing countries, agriculture is the principal source of income for rural households. In Pakistan, agriculture is the main contributor to the GDP, agriculturalists in Pakistan endure poverty. It's true that agriculture in Pakistan depends on rain fed (most of the provinces have water crisis, if not all) and farmers are not using modern tools for farming; and most of them are uneducated. Consequently, production is inefficient and less produced with limited resources. Most of the farmers don't have their own bank account and insurance because financial sectors and insurance companies consider this area to be of high risk due to droughts, high price for the output, water crisis, problematic in crisis of electricity and the resultant unproductivity and low income generation in this area during each and every production period. Non-farm options are not for everyone and agriculture alone can't support satisfactory livelihoods according to Gordon and Craig (2001). Basically non-farm income is important for an off-season for rural areas because the main activities are farming. Pakistan Social and Living Measurement Survey (PSLM) showed that 72 percent of rural households having income from non-farm sources (De Janvry et al., 2005). This sector is making impact on employment and subsidiary on the livelihood of farming households, yet how it distresses agricultural yield in Pakistan remains largely unknown. In this study we will try to determine the impact of non-farm income of households on agricultural productivity in rural areas of Pakistan by reckoning the influences of non-farm income on farm income.

\section{Literature Review}

In developing nations like Pakistan in which farming plays a crucial role in their economy, nonfarm economy as such is playing a significant role in household agriculture income system when we make comparison in return (farm return vs. nonfarm return). For many years, Pakistan's rural economy have relied mostly on agriculture sector but its altering the situation is changing nowadays. Day by day income gaps are emerging between incomes gained from non-farm household and farm households as stated by Chang and Boisvert (2006). Most of the scholars found that in the rural areas percentage of poor people beats the ability of agriculture to provide maximum job opportunities (Gordon and Craig 2001). According to Marsland, et al (2000), lots of poor people are migrating from rural to urban areas but it is not certain if urban areas can secure their jobs because they are not able to proceed with farming or agricultural activities in the urban areas. In rural areas if farming is failed, then non-farm can be considered off seasonal complement economic source. But in the rural areas intense labor is needed to manage the non-farm activities. It can also generate more risk (Gordon and Craig; 2001). In most of the developing nations, non-farm income created 29-46 percent of rural household income (Hazell, and Reardon;2005). According to Readon et al., (1998) 42 percent share of household from non-farm household from Africa, 32\% from Asia, 40 percent from Latin America. Reardon et. al., (1997) stated that association amid nonfarm and farm sector can be studied by using nonfarm and farm linkages. Basically farm/non-farm linkages are transactions that are financially being done by some time. In addition, there is a peculiar linkage among production and expenditures with them. Basically, for the production linkage there are 
two variations: upwards and downwards. Upward production linkages are found in the non-farm sector when agricultural output is used as input (Woldenhanna, 2000). On the other hand, non-farm accomplishments that deliver input to agricultural production like agrochemicals, nourishments and pumps etc. to supply the Argoprocessing and delivery services non-farm sector is fortified to invest (Reardon et al., 1997; Davies et al., 2003). Upward and downward production relations are mostly related with local agriculture (Reardon et al., 1997). It would become vibrant if non-farm and farm expenditure can be possible when household earning and spending is possible one sector to another. For example, if a farmer buys products related to non-farm, income would be generated from farm accomplishments. Depletion linkages are made when expenditure is related to household depletion. Farm income increases the demand for basic goods and services and results in divergent ways of consumption (Woldenhanna, 2000). Superfluous returns from non-farm can be used in farm activities, and then it will aid the agriculture production (Davies et al., 2003). Productivity and expenditure depends on the circulation of the income. Most of the Pakistani agriculturists are very poor. The poor are mostly investing in local goods and service but rich households are more likely to invest in urban and modern sectors. According to Davies et al. (2003), if noteworthy external inputs are needed for agricultural invention, then it is predictable that backward invention linkages will occur. Agricultural output requires dispensation before selling, therefore, it induces forward production linkages. If growth in the agricultural sector is proficient to persuade rural income growth, then depletion and potential investments will be superior by expenditure ties. Probable reaction on struggle for labor and credit; on the other hand, positive impact of non-farm income on household flat is suggested in the literature (Ellis; 1998). Time and space is explicit for net impression of nonfarm activities. When market is experiencing scarcity then non-farm income affects agriculture production, the effects can be direct or indirect. Indirect effects for non-farm show budget constraints and the pressure to buy bulk amount of normal goods. Indirect effects are more complicated: security, higher amount of investment needed for farm inputs, and so on. According to Reardon et al. (1994), it is an immense challenge for households if they jointly want to work on non-farming and farming with inadequate resources, capital and labor force. Inadequate resources need to be reorganized in order to contribute in non-farm activities and these results would inevitably lead to the withdrawal of critical resources from the farming, if high returns from the non-farm activities are secured. Meanwhile, agriculture investment will be risky and it will also obstruct the maintenance of agricultural technologies (Reardon et al. 2001). High returns and productivity of non-farm activities grasp the attention of resources on rural farm accomplishments (Reardon et al. 2001). The significance is that non-farm activities can obstruct their own farm productivity by households (Ellis and Freeman; 2004). At this stage, agriculture production will decline and so does farm income. It also obstructs the agricultural financial gain or reconstruction (Ruben and van den Berg 2001). Both performance and significance relied on relative returns to farm and non-farm activities. In a nutshell, the contribution of non-farm economic activities to rural households will be influenced by plenty of factors that play a key role in decision-making. Attractive incentives and labor resources are triggering point in the field of non-farm activities, but in farm sectors such opportunities are missing. Some farm households are contributing to non-farm economy without any observation or motive. Participation in non-farm activities provide livelihood opportunities for poor rural households, and it also plays a pivotal role in development and in alleviating poverty if non-farm prospect be detained by the rural poor households. Previous studies have shown evidences of non-farm affecting the agriculture production positively or negatively, either boosting production or leading to reduction. Non-farm can also invest in farm sector to increase production, or farm income can be invested in non-farm sector from which the profits made would be later invested back in the agriculture sector.

\section{Data}

The current research collected data from Pakistan Social and Living Standards Measurement Survey (PSLM) 2014-15. Pakistan Federal Bauru of Statistics has developed its own sampling frame for rural and urban areas, up-dated in 2014-15. There is a comprehensive detail that is related to agriculture and nonagriculture; even income generation and private income transmission or transmittal is covered. Each area is split into enumeration blocks. Pakistan Social and Living Standards Measurement Survey (PSLM) 2014-15 representative sample 579 shows enumeration areas and 8687 households. It also covers 37128 members of household. 5069 belonged to rural area from the 8687 households. This research uses questionnaire as data collection instrument. It focuses on who operated farm and rural non-farm activities simultaneously; total urban households were 4056 in the survey. Researcher considered data both of them where farm and non-farm income activities in household. 


\section{Theoretical Background}

The model we used in our research is advocated by Huffman (1991); it shows the different activities as well as non-farm work where farm households assign their time. This model is based on agriculture household and its combined production of agriculture, consumption of household and also non-farm resolution in a single framework. These are assessments made by households. Basically two kinds of activities are considered in this research: farm work and non-farm work in household. Exploited utility functions implicitly in household and it's defined over consumption of goods Q and leisure, $H$, that is $U=U(Q, H)$. Maximized subject is utility to financial plan, invention, time and positive limit. The time limit is:

$T=L_{1}+L_{2}+H$; here $\mathrm{T}=$ total time used in farm and non-farm work respectively $\mathrm{L}_{1} \& \mathrm{~L}_{2}$ and $H=$ leisure as we mentioned before. Cash income of financial plan limit on household can be articulated as:

$P Q=p 1 y 1-w 1 L 1+w 2 L 2+R$

$$
P=\text { Price }
$$

$w_{1}$ and $w_{2}=$ Returns to farm and non-farm work labor.

$y_{1 \text { and }} p_{1}=$ Farm output production and sold price for farm output in annually and $\mathrm{R}=$ income of non-

Farm work and non-farm work optional time portion and leisure (first order condition):

$$
\frac{\delta U}{\delta L_{i}}=w_{i} \frac{\delta U}{\delta Q}-\frac{\delta U}{\delta L}=0
$$

For the farm and non-farm, work can be reshuffled from the first order condition such as:

$$
w_{i}=\frac{(\partial U / \partial L)}{(\partial U / \partial Q)}
$$

Three accomplishments are household assign their time and labor supply functions for farm and nonfarm work can be derived as:

$$
\begin{aligned}
& L_{1}=L_{1}\left(w_{1}, w_{2}, p_{1}, p_{2} ; Z\right) \ldots \\
& L_{2}=L_{2}\left(w_{1}, w_{2}, \quad p_{1}, p_{2} ; R ; Z\right)
\end{aligned}
$$

According to Huffman (1991), $i$ belongs to household of positive number of non-farm house, As noted by Huffman (1991), a constructive number of non-farm hours will be observed for household $i$, if the possible souk wage $\left(w_{i}^{m}\right)$ is larger than the reservation wage $\left(w_{i}^{r}\right)$

$$
L_{i}=1 \text { if } w_{i}^{m}>w_{i}^{r} \text { and } L_{i}=0 \text { if } w_{i}^{m} \leq w_{i}^{r}
$$
variable

We cannot observe differential wages. Index function can be specified and i is an unobservable 


$$
\begin{aligned}
& L_{i}^{*}=\beta Z_{i}+\mu_{i} \\
& L_{i}=1 \text { if } L_{i}^{*}>0 \\
& L_{i}=0 \text { if } L_{i}^{*} \leq 0
\end{aligned}
$$

Here $Z_{1}=$ Vector Variable (Location effect the non-farm income) $\mu_{i}=$ Chance disturbance period. From the linear function we can start to analyze the impact of farm and non-farm income.

$Y_{i}=\lambda_{i}+\alpha_{i} X_{i}+\delta_{i} L_{i}+\varepsilon_{i}$

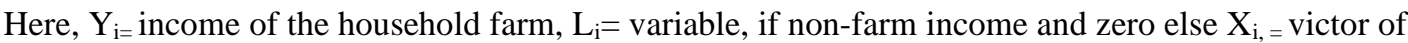
assets, personal or household physiognomies and location physiognomies, $\lambda_{i}=$ unidentified factors of vector and $\varepsilon_{\mathrm{i}}=$ Error

\section{Method of Empirical Estimation}

From the agriculture household, non-farm income contribution impact can be projected by using per capita income. Household engaged in agriculture production where it regulates the other factors as proxy. Methodology supports that there is methodical variance between households engaged in agriculture production and recognizable distinctiveness at household and community levels is apprehended by agriculture production. For the estimation the Heckman (1979) two-step procedure was identified. In the non-farm work, farm household participation decision needs to estimate so that a decision model will be identified. We will go through two phases: the first stage is regression and the second is to select the model and then to recognize the non-farm income impact on per capita farm income. For the selection equation this research uses Probit equation. $i=$ (observation) probability of household receives non-farm income; if household is getting nonfarm income then $y_{l}=1$; on the other side if it is not getting then $y_{i}=0$. Function of the explanatory $Z_{i}$ researcher estimates the probability if episode arises.

Normal c.d.f ${ }^{1}$ for probit model then F:

$$
\operatorname{Pr} o b\left(y_{i}=1\right)=\phi\left(\beta Z_{i}\right)
$$

Here $\varnothing$ is $=$ cumulative density function and $\beta=$ vector of unknown perimeter.

0 and 1 always fall in desired property for the c.d.f. so we can write function; ... $\phi\left(\beta Z_{i}\right)=\int_{-\infty}^{\beta Z_{i}} \phi(\varepsilon) d \varepsilon$

$\mathrm{B}=$ Max likelihood.

Probit model is the empirical model and it is for household recipients. Non-farm income can be estimated as :

$y=\beta_{0}+\beta_{1}$ agehd $+\beta_{2}$ agesq $+\beta_{3}$ educhd $_{\mathrm{j}}+\beta_{4}$ hhsize $+\beta_{5}$ ach $+\beta_{6}$ tel $+\beta_{7}$ mkt $+\beta_{8}$ bnk $+\beta_{9}$ tr $+\beta_{10}$ ptrans $\beta_{11}$ elec $+\beta_{12}$ ezones $_{i}+\varepsilon_{i}$ (viii) 


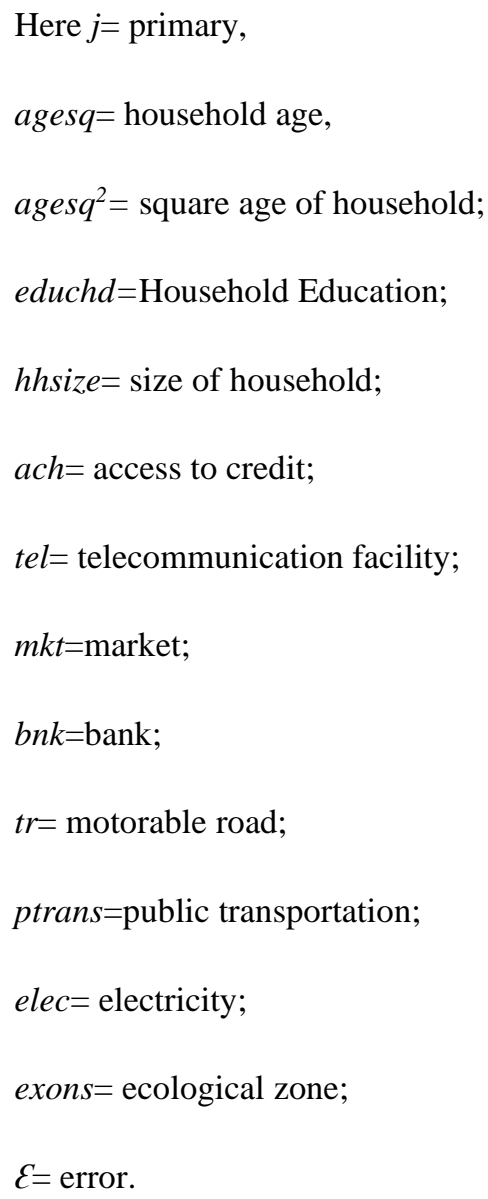

Sample selection is needed for using equation number viii. Dependent variable is only experiential for the constraints and non-aleatory sample so selection can be biased. Selection into nonfarm contribution may not be random and here selection can be biased and therefore the opposite mills ratio would be projected to deal with this probable problem. Inverse Mills ratio (Lambda) is another name to generate this selective term where number viii equation is used and equation ix used for per capita for farm income but in the second stage Heckman's two step procedure is used to justify on the basis of previous substantiation for the existence of self-section.

\section{Potential Endogeneity Problem solving}

Potential endogeneity problem solving is imperative for all studies. In fact, an independent variable is related with model that is potentially a choice variable, correlated with impalpable consigned to the error issue. In the dataset, the response variable for all the data points was keenly observed. It is true that non-farm income effect on farm income have greater likelihood to face an endogeneity issue. Farm income can invest for non-farm economy and non-farm income can be invested in the agriculture production simultaneously. On the other hand, it will be working in two directions effect. To solve the endogeneity problem, equation ix is projected where $y=$ continuous variable for non-farm income to forecast value which is considered in the equation, therefore OLS regression is second stage for per capita income equation.

$y=\beta_{0}+\beta_{1}$ agehd $+\beta_{2}$ agesq $+\beta_{3}$ educhd $_{\mathrm{j}}+\beta_{4}$ hhsize $+\beta_{5}$ ach $+\beta_{6}$ tel $+\beta_{7}$ mkt $+\beta_{8}$ bnk $+\beta_{9}$ tr $+\beta_{10}$ ptrans $+\beta_{11}$ elec $+\beta_{12}$ ezones $_{i}+\varepsilon_{i}$ 


\section{Estimate the Heckman Sample Selection}

Non-farm income can be part of independent variables because impact of non-farm income on farm income is projected within a linear regression framework through placing the forecast values for households. Equation $\mathrm{x}$ shows the linear regression.

pay $_{i}=\lambda_{0}+\lambda_{1} e d u c h d_{i}+\lambda_{2}$ hhsize $+\lambda_{3} f_{\text {size }}+\lambda_{4} v f i n v+\lambda_{5}$ fbo $+\lambda_{6}$ ezones $_{j}+\lambda_{7}$ prdnfe $+\lambda_{8}$ invmills $+\mu_{i}$

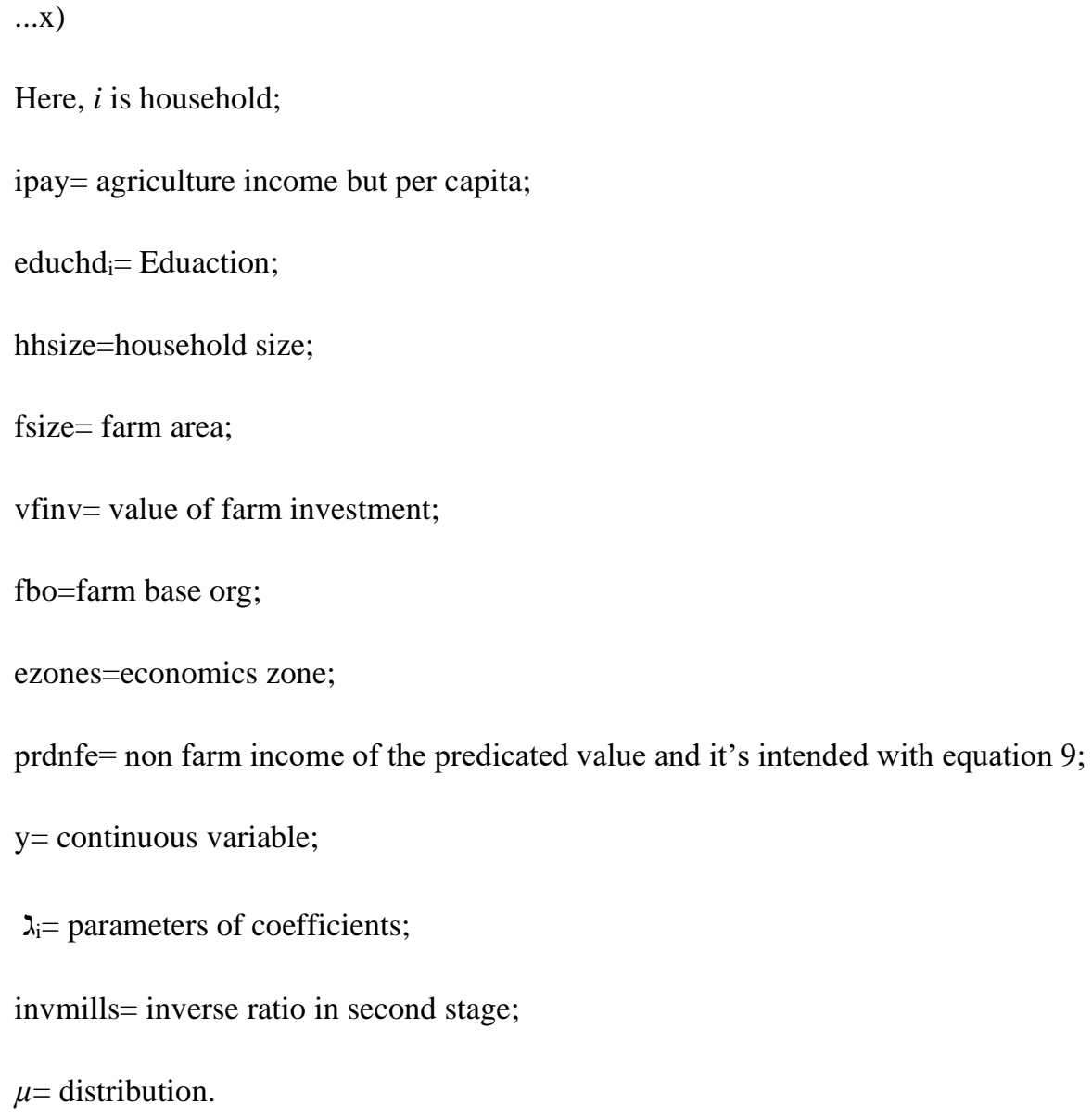

From the estimate the parameters of $\lambda_{9} \quad$ can measure the influence of non-farm income on household per capita agriculture income. According to Wooldridge, (2005), Inverse mills ratio is basically selfselection term by won choice which make participation into certain programmes or behaviors that are not casually determined. Wooldridge (2005) further explained that the term is mostly used when a binary indicator of contribution might be systematically correlated with unnoticed factors. In our study, farmers were selected by own choices and it can be non-farm addressee or others. But in Pakistan, those who select non-farm addressee have relatively high income. Meanwhile $\lambda=$ not exogenous variable then equation (x) OLS method will give inconsistent outcomes and biased estimates. To get the reliable result, the Hackman Sample Selection Model (two procedure) by Heckman (1979) and Maddala (1983) is considered and used in this research. Then sample selection is included and estimated. In this case equation 11 is already beyond explanation. 


$$
y_{i}^{*}=\beta Z_{i}+\mu_{i}, \quad y^{*}=1 \quad \text { if } y^{*}>0 ., 0 \text { otherwise }
$$

Here, $\mathrm{y}^{*}=$ non farm participation; $\mathrm{Z}=$ independent variable (Influence of participation of non-farm); $\beta=$ unidentified parameters; $u=$ error as $\mu\left(0, \sigma^{2}\right)$.

Probit model is equation xi. If household gets non-farm income then the participation estimate equals to $i$, if not then 0 otherwise, regressed on the independent variables. Number xi equation shows that exogenous variable is non-farm income and those who are receiving non-farm income in household are improving the farm and also retreating the food status.

\section{Experiential Outcomes and Discussion}

This section provide the Explanatory statistics and demographic information of the respondents [Table A1 and A2] as well.

Table A1: Explanatory Statistics of Independent Variables for Econometric Analysis

\begin{tabular}{llllll}
\hline Variable & Obs & Mean & Std.Dev. & Min & Max \\
\hline Age of Household (Head) & 4056 & 42.1987 & 16.1342 & 16 & 99 \\
Age squared & 4056 & 2040.979 & 1578.7940 & 256 & 9801 \\
Household Size & 4056 & 5.0483 & 3.0343 & 1 & 29 \\
Log of Non-farm Income & 4056 & 12.3335 & 2.1227 & 0 & 18.2886 \\
Log of Agric Income & 4056 & 13.7914 & 1.4036 & 6.2729 & 18.1425 \\
Log of Farm Size & 4056 & 1.6185 & 0.8071 & 0.1823 & 8.9227 \\
Log of Val of Farm Invest & 4056 & 12.3927 & 1.4286 & 7.6009 & 19.1727 \\
\hline
\end{tabular}

Data: Social and Living Standards Measurement Survey (PSLM) 2014-15; Author Calculation

Table A2: Explanatory Statistics of Independent Resounding Variables for Econometric Analysis

\begin{tabular}{|c|c|c|c|}
\hline Variable & Frequency & Percent & Cumulative \\
\hline \multicolumn{4}{|l|}{ Non-farm Income } \\
\hline Participate & 3,433 & 84.64 & 84.64 \\
\hline Do not Participate & 623 & 15.36 & 100 \\
\hline \multicolumn{4}{|l|}{ No Education } \\
\hline Yes & 668 & 16.47 & 16.47 \\
\hline No & 3,388 & 83.53 & 100 \\
\hline \multicolumn{4}{|l|}{ Basic Education } \\
\hline Yes & 819 & 20.19 & 20.19 \\
\hline No & 3,237 & 79.81 & 100 \\
\hline \multicolumn{4}{|l|}{ Secondary Education } \\
\hline Yes & 594 & 14.64 & 14.64 \\
\hline No & 3,462 & 85.36 & 100 \\
\hline \multicolumn{4}{|l|}{ Higher Education } \\
\hline Yes & 2,798 & 68.98 & 68.98 \\
\hline No & 1,258 & 31.02 & 100 \\
\hline \multicolumn{4}{|l|}{ Farmer-Based Org. } \\
\hline Member & 635 & 15.66 & 15.66 \\
\hline Non-member & 3,421 & 84.34 & 100 \\
\hline \multicolumn{4}{|l|}{ Availability of Bank } \\
\hline Available & 260 & 6.41 & 6.41 \\
\hline Not Available & 3,796 & 93.59 & 93.59 \\
\hline \multicolumn{4}{|c|}{ Availability of Telecom } \\
\hline Available & 908 & 22.39 & 22.39 \\
\hline Not Available & 3,148 & 77.61 & 100 \\
\hline \multicolumn{4}{|c|}{ Availability of Motorable Road } \\
\hline Available & 3,201 & 78.92 & 78.92 \\
\hline Not Available & 855 & 21.08 & 21.08 \\
\hline \multicolumn{4}{|c|}{ Availability of Market } \\
\hline Available & 562 & 13.86 & 13.86 \\
\hline Not Available & 3,494 & 86.14 & 100 \\
\hline
\end{tabular}


Access to Credit

\begin{tabular}{llll} 
Access & 1,449 & 35.72 & 35.72 \\
No Access & 2,607 & 64.28 & 100 \\
Available & 2,424 & 59.76 & 59.76 \\
\hline
\end{tabular}

Data: Social and Living Standards Measurement Survey (PSLM) 2014-15; Author Calculation

Table A2: Explanatory Statistics of Independent Resounding Variables for Econometric Analysis (Con'd)

\begin{tabular}{|c|c|c|c|}
\hline Variable & Frequency & Percent & Cumulative \\
\hline \multicolumn{4}{|c|}{ Availability of Public Transport } \\
\hline Not Available & 1,632 & 40.24 & 100 \\
\hline \multicolumn{4}{|c|}{ Availability of Electricity } \\
\hline Available & 901 & 22.21 & 22.21 \\
\hline Not Available & 3,155 & 77.79 & 100 \\
\hline \multicolumn{4}{|l|}{ Ecological Zones } \\
\hline \multicolumn{4}{|l|}{ Coastal } \\
\hline Yes & 3329 & 82.08 & 82.08 \\
\hline No & 727 & 17.92 & 100 \\
\hline \multicolumn{4}{|l|}{ Forest } \\
\hline Yes & 2341 & 57.72 & 57.72 \\
\hline No & 1715 & 42.28 & 100 \\
\hline \multicolumn{4}{|c|}{ Montane grasslands and shrublands zone } \\
\hline Yes & 2442 & 60.21 & 60.21 \\
\hline No & 1614 & 39.79 & 100 \\
\hline
\end{tabular}

Data: Social and Living Standards Measurement Survey (PSLM) 2014-15; Author Calculation

Also in this section, researcher discussed the explanation of probit regression result and also shows the OLS regression model for non-farm income and per capita agriculture income correspondingly. Probit regression model is projected the probability of a household being a non-farm income beneficiary while impact of non-farm on agriculture income is projected by OLS regression model. Non-farm income received and per capita agricultural yield is shown in Table A3 and A4 (below) from the probit estimation and Heckman Selection model correspondingly.

Table A3: PE of Non-Farm Income Contribution Decision Assessment

\begin{tabular}{|c|c|c|c|c|}
\hline Variable & Coefficient & Standard Error & z-stat & $\mathrm{p}$-value \\
\hline Age of Head of Household & 0.0031 & 0.0082 & 0.38 & 0.706 \\
\hline Age Squared & 0.0000 & 0.0001 & -0.21 & 0.831 \\
\hline \multicolumn{5}{|l|}{ No Education (Ref. Group) } \\
\hline Basic Education & 0.0924 & 0.0811 & 1.14 & 0.255 \\
\hline Secondary Education & 0.0106 & 0.0696 & 0.15 & 0.879 \\
\hline Higher Education & 0.0205 & 0.0734 & 0.28 & 0.78 \\
\hline Household Size & -0.0004 & 0.0083 & -0.05 & 0.958 \\
\hline Access to Credit & 0.0841 & 0.0519 & 1.62 & 0.105 \\
\hline Availability of Telecom & -0.2342 & 0.1204 & -1.95 & $0.052 *$ \\
\hline Availability of Market & 0.0979 & 0.0784 & 1.25 & 0.212 \\
\hline Availability of Bank & -0.2244 & 0.0944 & -2.38 & $0.017 * *$ \\
\hline Availability of Motorable Road & 0.2305 & 0.0716 & 3.22 & $0.001 * * *$ \\
\hline Availability of Public Transport & 0.0593 & 0.0649 & 0.91 & 0.361 \\
\hline Availability of Electricity & 0.1417 & 0.1224 & 1.16 & 0.247 \\
\hline \multicolumn{5}{|l|}{ Coastal Zone (Ref. Group) } \\
\hline Forest Zone & -0.1614 & 0.0714 & -2.26 & $0.024 * *$ \\
\hline Montane grasslands and Shrublands zone & -0.2182 & 0.0712 & -3.06 & $0.002 * *$ \\
\hline Constant & 0.8382 & 0.2057 & 4.08 & $0.000 * * *$ \\
\hline Number of Obs & 4056 & & & \\
\hline LR $\operatorname{chi}^{2}(15)$ & 48.13 & & & \\
\hline Prob $>\mathrm{chi}^{2}$ & 0.000 & & & \\
\hline Pseudo $\mathrm{R}^{2}$ & 0.0138 & & & \\
\hline
\end{tabular}

According to Nakosteen and Zimmer (1980), in the second stage of estimation procedure, multicollinearity issues will arise by inclusion of all predictor's variables in both decision and equation of agriculture income. Consequently, lots of things enclosed in regression in the non-farm income decision equation such as 
access to credit, telecommunication, bank, electricity, motorable roads and convenience of public transportation. On the other hand, agriculture income equation is not added.

Table A4: Estimations of the OLS Model Variables (HS Model)

\begin{tabular}{|c|c|c|c|c|}
\hline Variable & Coefficient & Standard Error & Z-stat & p-value \\
\hline Non-Farm Income & -0.0194 & 0.0091 & -1.95 & $0.052 *$ \\
\hline Age of Head of Household & 0.0126 & 0.0068 & 1.86 & $0.063^{*}$ \\
\hline Age Squared & -0.0001 & 0.0001 & -1.82 & $0.070 *$ \\
\hline \multicolumn{5}{|l|}{ No Education (Ref. Group) } \\
\hline Basic Education & -0.0246 & 0.0662 & -0.37 & 0.710 \\
\hline Secondary Education & -0.1246 & 0.0574 & -2.17 & $0.030 * *$ \\
\hline Higher Education & -0.0780 & 0.0595 & -1.31 & 0.190 \\
\hline Household Size & -0.1282 & 0.0071 & -18.09 & $0.000 * * *$ \\
\hline Log of Farm Size & 0.3644 & 0.0264 & 13.81 & $0.000 * * *$ \\
\hline Log of Value of Farm Invest & 0.2658 & 0.0151 & 17.61 & $0.000 * * *$ \\
\hline \multicolumn{5}{|l|}{ Coastal Zone (Ref. Group) } \\
\hline Forrest Zone & 0.1167 & 0.0563 & 2.07 & $0.038 * * *$ \\
\hline Montane grasslands and shrublands zone & 0.0799 & 0.0569 & 1.41 & 0.160 \\
\hline Availability of Farmer-based Org. & 0.0222 & 0.0551 & 0.40 & 0.688 \\
\hline Inverse Mills Ratio & -0.0265 & 0.0449 & -0.59 & $0.055 *$ \\
\hline Constant & 10.2851 & 0.2402 & 42.83 & $0.000 * * *$ \\
\hline Number of Obs & 4056 & & & \\
\hline $\mathrm{F}(13,4042)$ & 71.37 & & & \\
\hline Prob $>\mathrm{F}$ & 0.000 & & & \\
\hline R-squared & 0.1867 & & & \\
\hline Adj R-squared & 0.1841 & & & \\
\hline
\end{tabular}

\section{Probit model Estimates}

Most of the time, households rely on convenience of bank, motor road and telecommunication frames. Estimation of Table A3 shows that there is chance to get the non-farm income of households. On the other hand, it's highly probable that telecommunication access will decrease with non-farm income as indicated by negative coefficient of telecommunication frame variable. By having the same attitude in the bank sector it's also significantly negative. It is true that rural households pay higher concentration on their farm activities until or unless they are not getting easy access to their consumers or customers in the urban centers to find their yield. Banks are not interested to give credit to non-farm sector as compared to farm households sector and have found a negative association with non-farm sector. According to GoP 2014, in Pakistan the daily wage of labor is $\$ 2$ and it clearly depicts the poverty. Due to poverty, large amount of rural households are deprived from education and even food security as well. Most of the household members are illiterate and they don't have any access to structural sectors like roads, market, and communication. They can't participate in economic activities though non-farm directly. Non-farm household participation is increasing with the passage of time due to the availability of motorable roads. It gives the sign of development as road is going to construct rapidly later non-farm and entrepreneur can participate enthusiastically.In Pakistan, coastal zone and forest zone gives a signal of positive sign. Moreover, montane grasslands and shrublands zone coefficients are significantly positive. By making comparison between farm household in coastal zone and other provinces we came to know that farm household may be highly appreciated to reduce non-farm income by GH $\not 0.1614$ and montane grasslands and shrublands zone also appreciated to reduce non-farm income by GHф0.2182. According to World Wildlife Fund, ed. (2001), the outcomes are not affirmed that montane grasslands and shrublands zone would participate more in non-farm income accomplishments. They showed that forest and coastal zone farmhouses would like to actively participate in non-farm income but in the mean time they also shows farm houses in forest zone are less interested to join non-farm income accomplishments. Non-farm income contribution is the first stage of Heckmen's two-stage model, which grasps the drivers of participation by employing binary probit equation in Table A3. Table A4 shows the "outcomes equation" and "per capita farm income" and Mills Ratio (Lambda) used to generate selectivity tenure for contribution equation. 


\section{Impact on Agricultural Productivity from Non-farm Income}

Table A4 is showing the regression output of Impact on Agricultural Productivity from Non-farm Income. Lots of literature strongly support that income spawned from non-farm cradles decrease/increase agriculture income. According to Pakistan Social and Living Standards Measurement Survey (PSLM) 201415 and Pakistan Federal Bauru of Statistics data, women are minor dominated in professional industry sector. Meanwhile, women can't withstand the farm. Most of the time, they switch from farm sector to non-farm sector eventually. Henceforth, rising income accumulate to this sector. In the meantime, it's not that men are inferior in the professional industry sector. To solve the endogeneity problem of non-farm income Ordinary Least Squares is projected in this research. Researcher also used Heckman modal is also used as exogenous variable from the projected values. Table A5 shows the findings of regression.

Table-A5: Ordinary least squares Regression of Non-farm Income and other Descriptive Variables

\begin{tabular}{|c|c|c|c|c|}
\hline \multirow[b]{2}{*}{ Variable } & \multicolumn{3}{|c|}{ Standard Error } & \multirow[b]{2}{*}{ p-value } \\
\hline & \multicolumn{2}{|l|}{ Coefficent } & t-stat0 & \\
\hline Age of Household (Head) & 0.0178 & 0.0109 & 1.64 & 0.102 \\
\hline $\begin{array}{l}\text { Age squared } \\
\text { No Education (Ref.Group) }\end{array}$ & -0.0001 & 0.0001 & -1.26 & 0.206 \\
\hline Basic Education & -0.0818 & 0.1064 & -0.77 & 0.442 \\
\hline Secondary Education & 0.0375 & 0.0927 & 0.4 & 0.686 \\
\hline Higher Education & -0.5465 & 0.0973 & -5.62 & $0.000 * * *$ \\
\hline Household Size & -0.0926 & 0.0112 & -8.3 & $0.000 * * *$ \\
\hline Access to Credit & 0.6071 & 0.0683 & 8.89 & $0.000 * * *$ \\
\hline Availability of Telecom & 0.1607 & 0.1575 & 1.02 & 0.308 \\
\hline Availability of Market & 0.0833 & 0.1006 & 0.83 & 0.408 \\
\hline Availability of Bank & 0.0368 & 0.1337 & 0.28 & 0.783 \\
\hline Availability of Motorable Road & 0.0165 & 0.0985 & 0.17 & 0.867 \\
\hline Availability of Public Transport & 0.4046 & 0.0849 & 4.76 & $0.000 * * *$ \\
\hline Availability of Electricity & -0.0561 & 0.1579 & -0.36 & 0.722 \\
\hline Coastal Zone(Ref.Group) & & & & \\
\hline Forrest Zone & 0.1012 & 0.0910 & 1.11 & 0.266 \\
\hline Montane grasslands and shrublands zone & -0.0532 & 0.0914 & -0.58 & 0.561 \\
\hline Constant & 12.1941 & 0.2737 & 44.55 & $0.000 * * *$ \\
\hline Number of Obs & 4056 & & & \\
\hline $\mathrm{F}(15,4040)$ & 24.01 & & & \\
\hline Prob $>F$ & 0.000 & & & \\
\hline R-squared & 0.0818 & & & \\
\hline Adj R-squared & 0.0784 & & & \\
\hline
\end{tabular}

***significant at $1 \% \quad * *$ significant at $5 \% \quad$ *significant at $10 \%$

Data: Social and Living Standards Measurement Survey (PSLM) 2014-15; Author Calculation

Table A4 mentioned that per capita non-farm income is negative and significant at level 10\%. It designates farm income per capita decreased by GHф0.0222 and boost the non-farm income per capita by GH $\notin 1$. According to Godwin and Mishra (2004) argument, day by day non-farm work participation is reducing on the farm and also reducing the agricultural production. So research findings also support this argument. Correspondingly, Lisa Pfeiffer; Alejandro López-Feldman; J. Edward Taylor (2009) fix up the same result on their studies that agriculture sector continually brings negative effect on non-farm sector and thus decreasing the labor supply to the farm. For the effect of non-farm income on household per capita farm income, Heckman's two-stage procedure also suggests OLP. Coefficient of the selective variable is significantly negative. There are lots of comments on that. This research selects Heckman Selectivity model supported by the statistical significance of the coefficients. Negative coefficient recommends the existence of unnoticed variables having different effect on non-farm income 
contribution decision and farm income. The age of head household coefficient is significantly positive at $10 \%$ level and it shows how it gains importance in farm sector.

We get to know from the output (positive coefficient) that the age of the household head per capita farm income rise by GH $₫ 0.01$ for the apiece additional increase. Nonlinear relationship between age and per capita farm income is suggested by age square of negative and significant coefficient and its $U$ shape relationship. It also suggests that farm household head of young age does not participate in non-farm agriculture sector, but household head of old age are coming in non-farm work sector, because most of the households think that they can do hard work and will get weaker. According to Sumner 1982; Abdulai and Delgado 1999, this study is unreliable and they got their previous studies result that as young farm household members increase in age, they tend to participate more in offfarm work but in their older ages, they work more on-farm. In the reference category there is no education in the section of education variable. GH $\not 0.1246$ is decreased per-capita farm income with secondary education and farm household heard. So, those who are getting secondary education have negative consequence on per capita farm income for every farm household. This is also helpful in expanding the involvement of non-farm work and cordially decreasing the involvement of farm work. Similarly, Lanjouw (1999) found that those who are in high education sector and playing great role in economic income sector have positive impact on their income but at the end they are showing negative consequences on agricultural sector. According to Islam, Nurul. (1997); the associated development is consistent with some aspects but the opposing view is that secondary education makes entrepreneurial spirit. So, for this reason, agriculture productivity income level of farm household sectors increases. On the other hand, primary education improves labor productivity. p-value less than $1 \%$ for household size and it has negative impact on per capita agriculture income. Researcher has concluded from the result that household size rising by agricultural individual per capita income decline by GHф0.13. The accredited fact is that the aged and adolescents are not active, and that they cannot do hard work in farm sector. Greater households make more aged and adolescents group. They make lower value of per capital output in agriculture sector. Researcher can discuss in different ways, farm household are younger and school aged so they can't participate actively in this area for income generation. This is the negative effect. According to Delgado,(1998), the married poor raises more children because they think that it promises care in their old age and provides more labor support in household. Most of the farm household children need more time to take care of their elderly parents, so it decrease the chance of extra per-capita income. That's why low-income household are in tension to make additional reinvestment. Lots of opportunities for large size farm such as diversification. They can do both perpetual and dumpy period squashy crops. This notion has always helped the farm household. It's extremely true that large farm size anticipate higher amounts of agricultural per capita income in all fields. Table shows that log of farm size is significant at $1 \%$. There is a positive impact on per capita agriculture income in household. Evidence supports that if farm size increase then per acres household agricultural income rises by $\mathrm{GH} \notin 0.3644$. Large farm size household is more productive for farm land, so it's easy to spawn higher per capita income in agricultural sector. The highlighted fact and result is that agricultural primary input is land. Log of value of farm investment (coefficient of the variable) is positive at $1 \%$ significant level. It is suggested that if log of the value of farm investment rise per unit then farm income per capita rises by $\mathrm{GH} \not 0.2658$. So it's proved that more investment means more per capita income and more agriculture productivity. But this result is not consistent with Lien's (2010) findings that more investment in farm sector decreases the per capita income in farm sector. Montane grasslands and shrublands zone have positive 
coefficient with forest zone but Montane grasslands and shrublands zone are not significant. Forest zone farm house can increase the per capita income in farm sector by $\mathrm{GH} \not 0.1167$ and significantly positive coefficient of forest zone is in comparison with coastal zone farm household. According to Seini (2002), this result makes sure that climate and geographical conditions have big impact on agricultural production, it can be positive or negative.

\section{Recommendations}

Pakistan is a developing country and rural nonfarm income is crucial for sustainable economic development of Pakistan. Indeed, non-farm participation development compromise on the production of agriculture and bulling the food security. In Pakistan, cross sectional data shows that in rural Pakistan, agriculture production is going to reduce the participation of nonfarm activities. Islamic republic of Pakistan knows that they need to boost the sustainable agriculture production. It's highly alarming that an increasing number of population and a lack of food supply would be import oriented which will have an impact on the entire economy. So, to fill up the augmented demand there is a need to take long-term initiatives for sustainable agriculture production. To makes the sustainable agriculture productivity, growth needs greater attention on farm by SMEs, men and women both. For the Islamic countries, norms, culture and values system are entirely different from western countries. There is a huge restriction for women to actively participate in agriculture sector equally but they provide tremendous support in the household. According to Samaa Tv (2017), report on population ratio in Pakistan is 105 men for 100 women in Pakistan. So, without active participation of woman no nation can develop in any sector.

Agriculture sector is uncertain for households, so most of the time the households prefer to invest in nonfarm sector which is less uncertain. However, these two sectors are competitive. The current research findings are consistent with previous studies and recommend that a need policy is required for agriculture unswervingly. For instance, financial institutes need to support the agricultural production, training institutes will need to help to give training on how farmer can become self-sustainer. Moreover, educational institute can play a pivotal role in agriculture sector. It is evident from the findings, there is a dire need to improve and reemphasize the school level education, including the agriculture related topics at the school level so that the student will be encouraged to do higher education on the agriculture sector. Ministry of Education in Pakistan can take another initiative to include agricultural science topics in elementary education sector. More new agricultural institutes need to be established with modern tech facility, availability tools, and research funds for to sustain researchers or to upgrade the existing ones with advanced technologies. Instructors must be skillful and get extensive knowledge through proper training and development. Last but not the least, nonfarm is rapidly growing and have a prosperous ground in Pakistan. It should not be promoted at the threat of agriculture since these two sectors are not considered supplementary to each other as in rural Pakistan, nonfarm participations is slightly reducing farm income. 


\section{Kaynakça/References}

Reardon, T., J.E. Taylor, K. Stamoulis, P. Lanjouw and A. Balisacan. 2000. Effects of non-farm employment on rural income inequality in developing countries: an investment perspective. J. Agric. Econom. 51(2): 266-288. https://doi.org/10.1111/j.1477-9552.2000.tb01228.x

De Janvry, A., E. Sadoulet. And N. Zhu. 2005. The role of non-farm incomes in reducing rural poverty and inequality in China. Department of Agricultural and Resource Economics, UCB.

GOP. 2014. Economic Survey of Pakistan. 2013-2014. Economic Advisor's Wing, Finance Division, Islamabad, Pakistan.

Lisa Pfeiffer; Alejandro López-Feldman; J. Edward Taylor (2009), Is off-farm income reforming the farm? Evidence from Mexico; Agricultural Economics, Volume: 40, Issue: 2: Pages 125-138.

World Wildlife Fund, ed. (2001). "Northwestern Himalayan alpine shrub and meadows". WildWorld Ecoregion Profile. National Geographic Society. Archived from the original on 2010-03-08.

Sumner, DA. 1982. The labor supply of farmers. American Journal of Agricultural Economics, 64: 449-509.

Abdulai, A and Delgado, CL. 1999. Determinants of nonfarm earnings-based husbands and wives in North Ghana. American Journal of Agricultural Economics, 81: 117-30.

Lanjouw, J. O. (1999); Rural Non-agricultural Employment and Poverty in Ecuador Article in Economic Development and Cultural Change 48(1):91-122 - February 1999; DOI: $10.1086 / 452448$

Islam, Nurul. 1997. The Non-farm Sector and Rural Development: Review of Issues and Evidence. Food Agriculture and Environment Discussion Paper 22. Washington: International Food Policy Research Institute.

Population census 2017: Men outnumber women in Pakistan (25 Augest,2017) https://www.samaa.tv/news/2017/08/population-census-2017-menoutnumber-women-pakistan/

Abdulai, A., and Delgado, C. L. (1999), Determinants of Non-farm Earnings of Farm Based Husbands and Wives in Northern Ghana. American Journal of Agricultural Economics, 81(1), 117-130.

Davis, J. R. (2003), The Rural Non-farm Economy, Livelihoods, and their Diversification: Issues and Options. (NRI report No: 2753). Chatham, Kent, UK: Natural Resources Institute.

Dimova, Ralitza, and Kunal Sen. (2010) Is household income diversification a means of survival or a means of accumulation? Panel data evidence from Tanzania. BWPI Working Paper 122

Ellis F. (2000) Rural Livelihood and Diversity in Developing Countries. New York; Oxford University Press.

Ellis, F. (1998) Household strategies and rural livelihood diversification. Journal of Development Studies, 35 : 1- 38.

Adams, R. H. and HE, J. J (1995), Sources of income inequality and poverty in rural Pakistan. International Food Policy Research Institute. Research Report, No. 102. Washington DC

Barrett, C.B. et.al. (2001), Non- farm Income Diversification and Household Livelihood Strategies in Rural Africa Concepts, Dynamics and Policy Implications.

Chang, H. and Boisvert, R. N. (2009) The Conservation Reserve Program, Off-farm Work, and Farm Household Technical Efficiencies. (Working paper 2009-33). Ithaca, New York, USA: Cornell University, Department of Applied Economics and Management.

Ellis, F. and Freeman, H.A. (2004) Rural livelihoods and poverty reduction strategies in four African countries. Journal of Development Studies, 40: 1-30.

Ellis, F. and Mdoe, N. (2003) Livelihoods and Rural Poverty Reduction in Tanzania. World Development Report Vol 31(8):1367-1384.

Pakistan Social and Living Measurement Survey (PSLM) 2014-15 [http://www.pbs.gov.pk/content/pakistan-social-and-living-standardsmeasurement]

Gordon, A., and Craig, C. (2001), Rural Non-farm Activities and Poverty Alleviation in Sub-Saharan Africa.

Natural Resources Institute, Social and Economic Development Department Policy Series 14. Chatham, UK

Haggblade, S., et. al. (2005), The Rural Non-Agricultural Economy: Pathway out of Poverty or Pathway in?Paper Presented at the Meeting of the International Food Policy Research Institute on the Future of Small-Farms, Washington D.C.

Heckman, J.J. (1979), Sample Selection Bias as a Specification Error. Econometrica 47(1), 153-161

Huffman, W. E. (1991), Agricultural household models: Survey and critique. In M. C. Hallberg, J. L. Findeis, and D. A.Lass (Eds.), Multiple jobholding among farm families (pp. 79-111). Ames, IA: Iowa State University Press. 
Islam, N. (1997), The Non-farm Sector and Rural Development. Food, Agriculture and Environment Discussion Paper No. 22.

Lanjouw, P. (1999) Rural Non-Agricultural Employment and Poverty in Ecuador, Economic Development and Cultural Change. 48(1) October

Maddala, G. S. (1983), Limited-Dependent and Qualitative Variables in Economics, New York: Cambridge University Press, pp. 257-91

Man, N., and Sadiya, S. I. (2009), Off-farm Employment Participation among Paddy Farmers in the Muda Agricultural Development Authority and Kemasin Semerak Granary areas of Malaysia. Asia-Pacific Development Journal, 16(2), 142-157.

Marsland, N. et. al. (2000), Policy and Research on the Rural Non-farm Economy: A review of Conceptual, Methodological and Practical Issues. Chatham, UK: Natural Resources Institute.

Reardon, T. (1997), Using Evidence of Household Income Diversification to Inform. A Study of the Rural Non- Farm Labour Market in Africa. World Development, 25(5), 735-747.

Reardon, T. (2001), Rural Non-farm Employment and Incomes in Latin America: Overview and Policy Implications. World Development, 29(3), 395-409.

Reardon, T., et.al.(1994), Links between Non-farm Income and Farm Investments in Africa Households: Adding the Capital Market Perspective. American Journal of Agricultural Economics, 76(5), 1172-1176.

Ruben, R. and van den Berg, M. (2001), Non-farm employment and poverty alleviation of rural farm households in Honduras. World Development, 26: 549-560.

Seini, A. W. (2002), Agricultural Growth and Competitiveness under Policy Reforms in Ghana. Technical

Publication No. 61). Legon: Univerity of Ghana, Institute of Statistical, Social and Economic Research (ISSER).

Senadza, B. (2011) "Non-farm Income Diversification in Rural Ghana: Determinants and Implications for Income Distribution and Welfare", VDM Verlag Dr. Mueller

Sumner, D. A. (1982) The Off-farm Supply of Farmers. American Journal of Agricultural Economics, 64(3), $499-509$.

Woldehanna T. (2000) Economic Analysis and Policy Implications of Farm and Off-farm Employment, A Case Study in Tigray Region of Ethiopia. Unpublished Master's Thesis, Wageningen University, Wageningen, the Netherlands.

Lien, G., Kumbhakar, S., \& Hardaker, B. (2010). Determinants of off-farm work and its effects on farm performance: the case of Norwegian grain farmers. Agricultural Economics, 1-10

Delgado, C., Hopkins, J., Kelly, V., Hazell, P., McKenna, A., Gruhn, P. (1998). Agricultural growth linkages in Sub-Saharan Africa. Washington, DC: IFPRI 